\title{
Ethnic Conflict in the Modern World- System: The Dialectics of Counter-Hegemonic Resistance in an Age of Transition
}

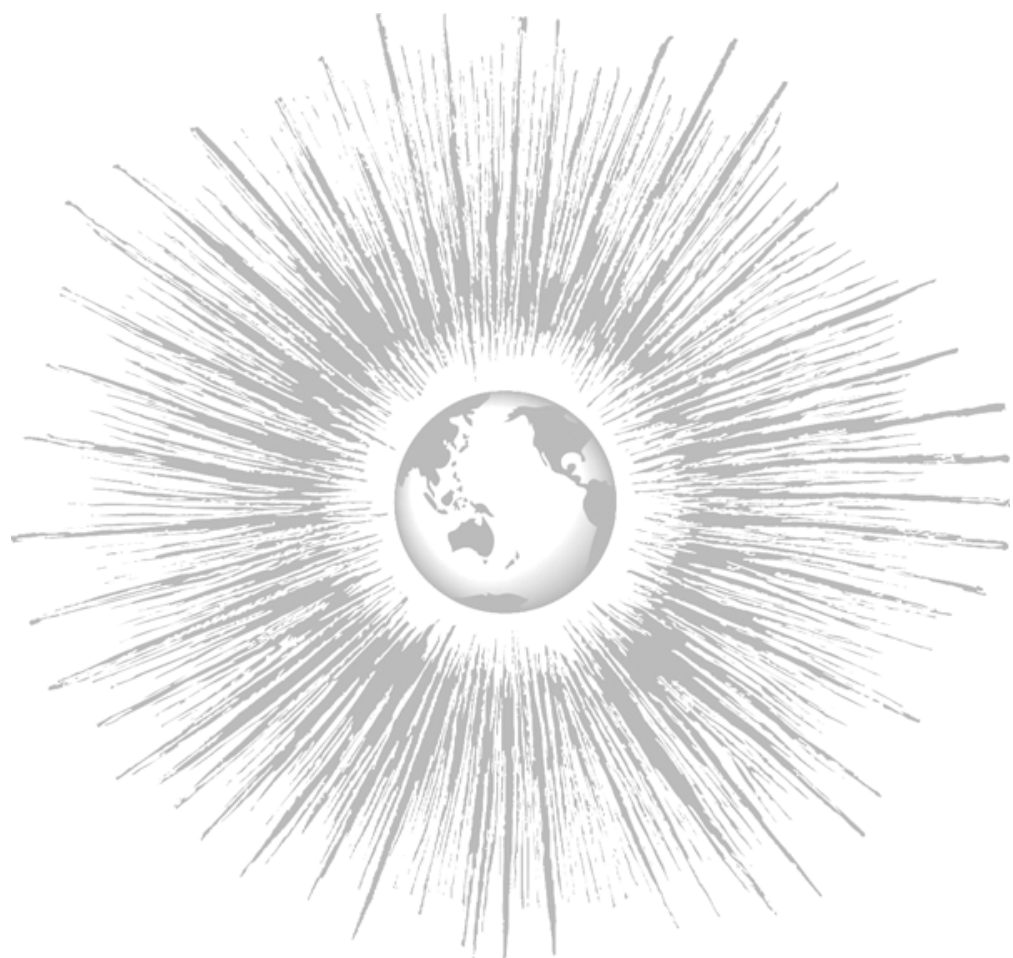

ABSTRACT

This article recasts debates about the extent and causes of ethnic conflict within the world-system framework. Ethnification and indigenism are inherent structural con tradictions of the modern world-system, and there is the highest incidence of ethnic resis tance at the peak of a hegemon's ascendancy. Consequently, there has not been a dramatic increase in ethnic conflict since the end of the Cold War. However, ethnic mobilizations pose an increased challenge to the continued func tioning of the world-system during the current age of transition. Ethnic mobilizations erode the capitalist civilizational project and increase costs to the system in ways that exacerbate the growing profit squeeze. I identify five ways in which the counter-hegemonic mobilizations of ethnic minorities are costly to the worldsystem and can push it toward bifurcation and transformation.
Wilma A. Dunaway

These multiple civilizations... are indeed the foci of important antisystemic movements. We may deconstruct more rapidly in their wake than without them. Indeed, can we deconstruct without them? I doubt it (Wallerstein I99ib:230).

\section{INTRODUCTION}

The modern world-system could not exist or survive without hegemonic ideologies that some have labeled "western civilization" (Huntington I996) or "modernity" (Bell 1976, Friedman 1989, Taylor 2000) and that Wallerstein (1983) terms the "capitalist civilizational project," that universalistic aggregate of beliefs, ideologies, and practices related to:

I. endless accumulation through economic growth and maximization of profits;

2. the commodification of everything;

3. geographical expansion to widen and deepen surplus extraction;

4. ecological imperialism, rationalization, and homogenization;

5. universalization of culture and knowledge production;

6. mythical construction of nations and peoples that are politically integrated into a tri-modal interstate system led by a hegemon;

7. racism and sexism to structure hierarchies of inequality;

8. repeated cycles of innovation, change, and expansion.

Wilma A. Dunaway

Department of Sociology

Virginia Polytechnic Institute \& State University

Blacksburg, VA 24061-0137

wdunaway@vt.edu

http://www.cas.vt.edu/sociology/

* I would like to thank Donald Clelland for his theoretical questioning, criticisms, and suggestions about earlier drafts of this article. I would also like to thank Franke Wilmer and Tom Hall for their comments and suggestions at the PEWS 2002 conference.

JOURNAL OF WORLD-SYSTEMS RESEARCH, IX, I, WINTER 2003, 3-34 http://jwsr.ucr.edu

ISSN 1076-I56X

(C) 2003 Wilma A. Dunaway 
Paradoxically, the world-system tends toward cultural hegemony while at the same time being characterized by relative autonomy of culture. Even though it has "transformed and circumscribed civilizations," the world-system has not obliterated the diversity of ethnicities and national cultures (Wallerstein I99ib: 192). Consequently, resistance against cultural universals has always been a central component of a majority of indigenous and ethnic struggles (Friedman 1993). However, any serious erosion or weakening of the capitalist civilization project is a threat to the survival of the world-system.

Given this structural contradiction between a totalizing civilizational project and the tendency toward heterogeneity, this paper will explore four questions:

I. How does the capitalist civilizational project create ethnic conflicts and ethnic mobilizations?

2. When does ethnic conflict increase?

3. How do indigenism and ethnification threaten or weaken the hegemony of the capitalist civilizational project?

4. Will indigenous/ethnic conflict push the world-system toward the bifurcation point and/or toward crisis leading to systemic change?

\section{IS THERE INCREASED ETHNIC CONFLICT IN THE WORLD-SYSTEM?}

There is a current scholarly preoccupation with describing ethnic and indigenous resistance as new phenomena that have suddenly become more dangerous. Many writers contend that postmodernism (Friedman 1992) or new forms of economic and cultural "globalization" (Smolicz 1998; Shulman 1998) are causing increased ethnic fragmentation all over the world. The United Nations (UNHCR 2002) posits "ethnic conflict" within and between adjacent countries as the predominant form of warfare that will occur in the $2 \mathrm{I}^{\text {st }}$ century. The Minorities at Risk Project (2002) provides the following empirical data about world levels of ethnic conflict. ${ }^{1}$

I. Between 1955 and 1996, there were 239 wars, regime transitions, and genocides in which inter-ethnic conflicts were the causative factors (Harff and Gurr 1997:5).

2. Between 1980 and 1996,60 distinct ethnic and religious minorities were victimized in wars and geno/politicides (Harff and Gurr 1997:8-10).

1. The Minorities at Risk Project defines "ethnic conflict" as (a) groups that are politically and/or collectively resisting state policies, (b) groups at risk of or that have been victimized by serious state repression, (c) violent or nonviolent collective conflict between groups, and (d) groups that engage in separatist movements.
Table 1 - Number of New Ethnic Groups Involved in Ethnopolitical Conflict, 1945-1999

\begin{tabular}{lccccccc}
\hline & \multirow{2}{*}{1945} & & \multicolumn{2}{c}{1989} & & \multicolumn{2}{c}{1999} \\
\cline { 2 - 3 } \cline { 6 - 7 } \cline { 6 - 7 } \cline { 6 - 7 } Region & \# Conflicts & & \# Conflicts & \% Change & & \# Conflicts & \% Change \\
Europe & 7 & & 7 & 0 & & 10 & +43 \\
Middle East & 6 & & 13 & +117 & & 6 & -54 \\
Asia & 12 & & 20 & +67 & & 28 & +40 \\
Africa & 1 & & 17 & +1700 & & 23 & +35 \\
Latin America & 0 & & 23 & +2300 & & 3 & -74 \\
World & 26 & & 62 & +139 & & 70 & +13 \\
\hline
\end{tabular}

Source: Analysis of data from the Minorities at Risk Project reported in Gurr (1994: Table 1). Note: Ethnopolitical conflict is defined as political rioting, local rebellions, guerilla activity, civil war, or inter-communal warfare. Groups participating in more than one type of conflict in a decade are counted only once. Conflict that was begun in a previous decade is not counted as a new conflict in the next decade.

3. At the end of the I990s, there were 275 groups in 116 countries-representing nearly one-fifth of world population-at risk of (a) violent repression from their national governments, (b) initiating open rebellion again a national government controlled by representatives of another ethnic group, or (c) engaging in violent collective action against other groups (Gurr 1999: Table I).

4. At the turn of the $2 \mathrm{I}^{\mathrm{st}}$ century, one-quarter of the population of Latin America and the Caribbean and one-third of the population of Africa and the Middle East are at risk of open ethnic conflict (Gurr 1999: Table 3).

Are we now seeing a dramatic "renaissance of ethnicity" (Friedman I988: 453) that exceeds what is typical of the world-system? Does this level of conflict represent an increase over earlier levels of ethnic conflict in the world-system? Ethnopolitical conflict nearly tripled between 1945 and 1989 when the United States was at the peak of its hegemony (see Table I), a trend opposite to that predicted by Friedman (1989:67). ${ }^{2}$ Contrary to the widespread scholarly perception, the contemporary period is characterized by a lower incidence of ethnic conflict than was typical of the world-system during the Cold War. Since the fall

2. Friedman (1989:67) argues that "it is primarily in periods of declining hegemony that such outbursts of cultural identification become a genuine possibility." 
Figure 1 - Percentage of Change in Number of New Groups Engaging in Ethnic Violence, 1945-1999

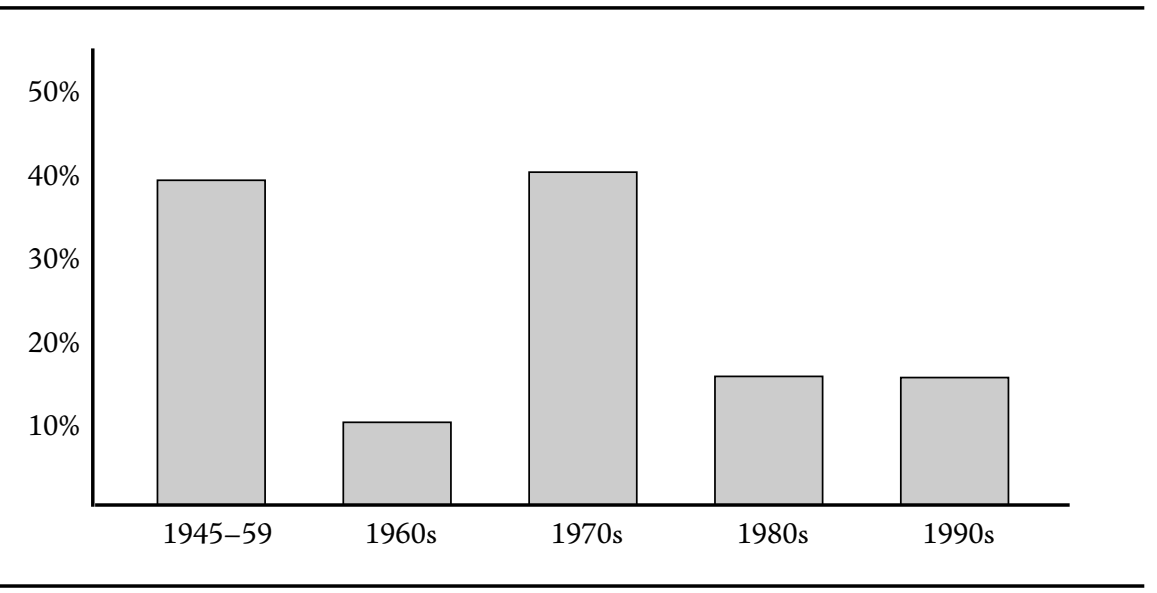

Source: Analysis of the data from the Minorities at Risk Project reported in Gurr (1994: Table 1). Ethnopolitical conflict is defined as political rioting, local rebellions, guerrilla activity, given decade. Groups are counted only once in any given decade.Violence initiated in a previous decade is not counted as a violence in the next decade.

of communism, worldwide ethnic conflict has increased at only about one-third of the level of increase that characterized the I950s and the I970s (see Figure I). In reality, ethnopolitical conflict increased at about the same pace in the I99os as it did in the I980s. In addition, more than half the conflicts reported in the I990s were continuation of mobilizations begun during previous decades. Moreover, "communal conflicts across fault lines between civilizations and religious traditions are more intense than others but have not increased in relative frequency or severity since the end of the Cold War" (Gurr 1994:352). Employing worldsystems analysis to investigate trends in ethnic conflict, Olzak and Tsutsui (1998:712) "question the claim that ethnic violence is exploding in the periphery" Indeed, they contend that "the periphery is no more likely than core countries to experience serious ethnic confrontations."

But world-system analysts are taking the wrong direction in claiming there must be more cases of ethnic conflict before such movements pose a threat to the capitalist civilizational project. World-system analysts need to be asking the question: is ethnic conflict more costly to the system now than in previous historical periods? That is the central question that this paper seeks to answer. Ethnic fragmentation is not new to the modern world-system, and it is not some
Ethnic Conflict in the Modern World-System

aspect of a new phase of postmodernism or of recent "globalization." ${ }^{3}$ First, ethnic identity formation and conflict are normal historical processes embedded in the logic and structure of the world-system from its very origins. Indeed, racism "came to serve as one of the pillars of the world-system as it historically evolved" since it functioned as the structural mechanism through which "the world division of labour would be assimilated' "into the universal capitalist culture (Wallerstein 1983:83). To rationalize surplus extractions, wealth concentration, and political inequities, the dominant group constrains those at the bottom through policies of polarization, exclusion, discrimination and repression (Cox 1959; Rodney 1973). Then it constructs myths and stereotypes that "ideologically camouflage" (Patterson 1982) its oppression and exploitation of ethnic minorities. The recurrent birth, restructuring, disappearance, and resurgence of ethnic groups results because marginalized minorities resist oppression. Consequently, "the history of the world has been the very opposite of a trend towards cultural homogenization; it has rather been a trend toward cultural differentiation, or cultural elaboration, or cultural complexity" (Wallerstein I99ib:I89). As a result, ethnic differentiation is no less a defining characteristic of the modern worldsystem than are the pressures toward cultural hegemony and national assimilation. In other words, ethnogenesis and minority group resistance are the bistoric norm-not contemporary aberrations!

\section{INCORPORATION, INDIGENISM AND ETHNIC FRAGMENTATION}

Today's ethnic conflicts result from the structural contradictions between cultural hegemony and ethnic heterogeneity that have been embedded by two historical processes essential to the world-system: incorporation and nation-building. Incorporation is the historical process by which external territories and peoples that have been outside are brought into the system through colonization, conquest, or economic and political domination (Hopkins and Wallerstein 1986). Following Hall (I986b, 200I) and Dunaway (1996a), I view incorporation as a process of the longue durée that is never complete and is always subject to resistance. At its most abstract level, integration into the capitalist world-system involves five concurrent macroscopic social changes:

3. On this point, I disagree strongly with Jonathan Friedman (1992:846) who contends that postmodernism is "giving rise to a myriad expression of ethnicities, religious cultures, and various traditionalisms" (Friedman 1988:450, 453). 
I. Economic production is transformed so that the zone is "dominated by capitalist relations of production" (Wallerstein 1979:162) and inextricably articulated through complex commodity chains with the capitalist world-economy (Hopkins and Wallerstein 1987:773; Wallerstein 1982: 15). That is, the means of production are captured by capitalists, the local economy is reorganized to prioritize export commodities, a surplus is extracted from cheap labor and ecological resources, and much of that surplus is drained to the core.

2. Local governance is centralized, and separate peoples are "unified" into states that can be articulated with the interstate system (Wallerstein 1984:404; Wallerstein 1974:349). Such states take various forms but are nearly always weak or "underdeveloped" in their relations to the core. State elites extract surpluses from their territories and ensure that a portion of those surpluses flow to the core.

3. Human beings are aggregated into a commodity-producing work force of semiproletarianized wage earners situated in households that subsidize capitalism through the unpaid labor of women and ethnic minorities (Dunaway 200I).

4. Natural resources are rationalized and homogenized, land is commodified into property that can be owned and redistributed, and the ecosystem is reorganized for capitalist production (Dunaway 1994, 1996a, 1996b).

5. After implantation of the capitalist civilizational project (Wallerstein I99Ib), the subsequent experience of alienation from long-accepted lifeworlds becomes the most disruptive aspect of incorporation. The construction of hybrid, adaptive cultures ensues, but real people experience the culturicide (Fenelon 1998) that follows incorporation's onslaught as death to their human dignity (von Werlhof 1997).

Most typically, external zones are integrated as peripheries of the world-economy; and the affected peoples quite often devolve from economic and political autonomy into dependence on a world-wide network of production (Dunaway 1994). Colonizers have used four mechanisms to bring indigenous people under their control. For those groups they do not annibilate, they pose three options: assimilate into the intruding culture; amalgamate and co-mingle traditions to create hybridized traits; or accommodate to external demands in order to coexist separately from the colonizer (Nagel and Snipp 1993). Clearly, these rivals are struggling to play out very different civilizational agendas. Because the geoculture of capitalism is grounded in racism, sexism, and universalism, capitalist interlopers exhibit an ethnocentric sense of superiority toward the society they are invading (Dunaway 1996b). Driven by the cultural logic of historical capitalism (Wallerstein 1983), the intruders mythologize their domination as a lofty mission to bestow "progress" on "backward barbarians" (Abdel-Malek I98I).

Universality creates cultural and cognitive imperialism, which establishes a dominant group's knowledge, experience, culture, and language as the universal norm. Dominators or colonizers reinforce their culture and values by bringing the oppressed and the colonized under their expectations and norms. Given the assumed normality of the dominator's values and identity, the dominators construct the differences of the dominated as inferior and negative.... This binary consciousness justifies the separation of Indigenous peoples from their ancient rights to the land and its resources and the transfer of wealth and productivity to the colonialists (Henderson 2000:63).

In sharp contrast to the imperialistic goals of the interlopers, most members of the indigenous group seek to safeguard their established way of life and their ecological spaces (Champagne 1989; Taylor and Pease 1994). Consequently, incorporation is a dialectical historical process that involves both structural articulation with the world-system and human resistance against the capitalist civilizational project (Dunaway I996b). On the one hand, incorporation into the world-system "is largely beyond the will and control of the members of indigenous societies" (Champagne 1989:7). On the other hand, change is deterred and its devastating effects are ameliorated because the impacted people act, react and resist (Merrell 1989; Gutierrez 199I). As a result, the dominated confound, disrupt, and slow the agenda of the colonizers (Fanon 1965).

As it incorporates new zones, the modern world-system is inherently contradictory in its racialization of peoples. On the one hand, the incorporation process differentiates populations into powerful dominant ethnic groups and marginalized ethnic subalterns. "The concept of ethnic minority was virtually introduced, and many ethnic identities largely created, by the imaginings of European colonial powers concerned... with building majority coalitions to assuage their own vulnerability as minority rulers" (Kingsbury 1998:427). On the other hand, that historical process results in ethnogenesis (Roosens 1989), the construction and preservation of new "localized ethnic identities" (Friedman 1999:6) and "the formation of indigenous 'minorities' concerned with historical claims to sovereignty" (Fenelon I998:xiii). ${ }^{4}$ By structuring ethnic differentiation to rationalize inequalities, colonizers embedded ethnic and racial categories into the historical

4. Regarding the connection between ethnogenesis and colonialism, see Kingsbury (1998:427-28), Anderson (1987), Greenberg (1980), Lamar and Thompson (198I), Varese (1996), Sivaramakrishnan (1995), Chimhundu (1992), Novati (1996). For an excellent overview of ethnogenesis in the Americas, see Hall (200I). 
memory and the political economy of the world-system. Consequently, capitalist colonizers create and solidify the very ethnic identities that form the bases for ongoing resistance (Roosens 1989). "Ethnic conflict with historical roots in conquest, destruction, and domination, remains one of the strongest 'predictors' for ongoing internecine violence, and 'threats' to national stability or hegemony" (Fenelon I998:xiv).

Hegemony and dominance never completely obliterate the histories or cultures of indigenous peoples or ethnic minorities. By structuring and concretizing ethnic and cultural inequalities during the incorporation process, colonizers set in motion a "postcolonial ghost dancing" (Henderson 2000:63) in which the persistence of those marginalized groups is insured across many generations. ${ }^{5}$ Their pasts are resurrected again and again, repeatedly reinvented in response to crises (Wallerstein I991a:78; Friedman 1992:853). From its inception, then, the modern world-system has structured contradictions between its antithetical needs for cultural homogeneity and for ethnic heterogeneity (Bhabha 1994; Purnell 2002). This structural ambivalence is one of the central dilemmas of the modern worldsystem. The drive of world elites to produce a unified whole conflicts directly with their maintenance of a hierarchy of ethnic minorities who challenge that domination. As Wade (2001:854) observes, "diversity does not just break through the official image of homogeneity; it is contained within that image." Thus, incorporation has a dialectical impact on oppressed ethnic minorities who employ "a past defined by outsiders... to forge a viable cultural identity in the present" (Friedman 1992:844).

\section{ETHNIC FRAGMENTATION AND NATION-BUILDING}

Nation-building is the second dialectical process through which the modern world-system structurally differentiates ethnicities. Comprised of interacting subsystems that are held together by conflicting forces and long-term historical

5. The metaphor refers to the nineteenth century "ghost dancing"of western U.S. Indians who engaged in a cultural revitalization movement against white subjugation. The group rituals were intended to summon a new world order that abandoned "white ways" and was to be marked by the reincarnation of thousands of their dead warriors and the return of the herds of wild horses and buffalo to their original numbers. The U.S. government interpreted the religious movement as an indicator that several groups were coalescing to rebel, so the army exercised extreme repression, culminating in the 1890 Sioux massacre and death of Sitting Bull at Wounded Knee (Champagne 1983). processes, capitalism has been able to flourish precisely because the world-economy has had within its bounds a multiplicity of states (Amin 1982:15) that are linked together and legitimated by an interstate system which limits the degree to which any one state can restrain the capitalist world-economy (Wallerstein 2000:31I).

States play a second function for the world-system, for they are the entities that control rebellious minorities. To paraphrase Benedict Anderson (I99I: $6)$, the modern world-system "invented nations where they $\mathrm{d}[\mathrm{id}]$ not exist," and the modern nation is an imagined political community. The establishment of a sovereign state within the interstate system triggers the creation of a corresponding people, another "major institutional construct of historical capitalism" (Wallerstein I991a:84-85). The construction of peoplehood "has grown more and more important as the system has developed greater density. In this sense it is like sovereign statehood, which is also an essential pillar, and has also grown more and more important" (Wallerstein 2000: 308-309). The nation is constructed as "a fictive ethnicity" grounded in "a historical system of complementary exclusions and dominations which are mutually interconnected" (Balibar I99I: $37,49,62)$. For that reason, nationalism has been closely intertwined with the practices of racism, ethnocide, religious intolerance, and culturicide. Without those mechanisms, the state could neither control population movements within its geographical space nor coalesce a "people" around a common identity, civilizational project, and official history (Wade 200I:848).

According to Gramsci, nations simultaneously homogenize community while submerging differences. An uneasy, fictitious homogeneity is constructed through the equation of the dominant ethnic identity with the core of the nation and the location of subordinated ethnic identities at its peripheries (Hall I986a). In the case of a marginalized indigenous group, the nation structures within its bounds a "territorialized community" that is likely to be continually in conflict with the state (Alonso 1994:395). On the one hand, paradoxes of homogeneity and heterogeneity are negotiated by the state through political domination over ethnicized subjects. On the other hand:

nationalist re-presentations of the past, produced by those in control of the state system, appropriate and transform local and regional histories and the memories of subordinated groups through the strategies of naturalization, idealization, and de-particularization. Pasts that cannot be incorporated are privatized and particularized, consigned to the margins of the national and denied a fully public voice. Through these strategies, a selective tradition of nationalism, which is key for the consolidation of the idea of the state, is produced.... This tradition is critical to the construction of hegemony by agents and institutions of the state system (Alonso 1994:389). 
Powerful as that dominant ideology becomes, it is never totally hegemonic. Paradoxically, the vulnerability of nations and of the world-system lies within its own hierarchy of structured differences. National unity is inherently fragile because it is a mythical racial construct. Though required for hegemony over a population, "national interests" and cultural dominance are never fully paramount (Lawson 1990). Juxtaposed against the possibility of the hegemonic and homogeneous nation are "recurring revivals" of ethnic identity (Champagne I989; Nagel and Snipp 1993; Dunaway 1997), including struggles over territory that emerge most frequently in the periphery and semiperiphery, sporadically in the core. As a result, nations are caught in a political and cultural contradiction that has been historically structured by the logic of the world-system. On the one hand, there is "no diminution in the drive of nations to establish sovereignty" (Hutchinson 2000:666) because the world-system cannot exist without those nation-states (Wallerstein 2000: 3II). On the other hand, "the authority of nations... has always been qualified domestically and externally" (Hutchinson $2000: 665)$. Hence the "cannibalizing dialectic between tendencies to homogeneity and tendencies to heterogeneity" (Appadurrai 1990:2) forms the dilemma of the state. Nationalism and ethnicity "emerge side by side.... The modern worldsystem bases itself on both ideologies, seemingly in contradiction one with the other" (Wallerstein 2000:344). As a result, nation-building "creat[es] in it[s] wake 'peoples' [and] ethnic groups-in uneasy relationship to the states" (Amin I982:15).

As Chee-Beng (1997:264, 27I) points out, states concretize the identities of subnational groups when they single them out for discriminatory policies. On the one hand, "the formation and development of ethnic groups can be seen as a by-product of the process of state development and nation-building." On the other hand, every state concession to the grievances of an ethnic minority re-legitimates their identity and reinforces the persistence of the group. When states allocate resources by ethnic category, they trigger ethnogenesis around marginal economic and political statuses. In this regard, the group forms "an identity in response to the state system," and projects that identity and grievance agenda "in the public arena of a nation-state."

For three reasons, nation-states view indigenous groups differently from any other ethnic category. First, indigenous cultures exist as "conjunctural countercultures" (Wallerstein I99Ib:193) that continually critique the capitalist civilizational project and question the state's "official" history. Second, indigenous groups often demand autonomy from the states in which their communal lands are trapped. (Maybury-Lewis 1992:54-55). Third, they may seek to preserve economic activities and goals that conflict with state development agendas. Indigenous groups often reside in territories that are resource rich, and they reject the state's author- ity over those ecosystems and land. Since "territorial integrity is at the core of what it means to be a state," indigenous peoples challenge the ideological foundations of the nation at every turn. Friedman (1999:9) contends that:

there is no logical way that nation-states and indigenous movements can coexist without a change within the larger structure of the state itself, or by con-

cluding compromises that simply accentuate the ambivalence in the situation.

The articulation of indigeneity and the world system produces a whole set of new contradictions that are becoming salient in the current situation.

Through their "residual claims to sovereignty", indigenous peoples "resist devolution and disappearance." Even though colonizers "established sovereignty and military-political control, they never effectively quieted the prior claims. As long as pre-existing populations with national identities were present, their 'claims to sovereignty', not completely extinguished, provided a potential threat to hegemonic domination" (Fenelon 1998:8),

A second challenge to national sovereignty results from cross-national migration. To complicate the dialectical tendency toward ethnogenesis, the modern state must also contend with "forms of citizenship beyond the nation" (Tambini 200I:200). Graeber (2002:4) argues that "the main achievement of the nation-state in the last century has been the establishment of a uniform grid of heavily policed barriers" that are now threatened by two demographic trends. Indigenous peoples quite often exist in territories that lie within the boundaries of more than one country. Such subnational groups "escape the power of the nation-state to inform their sense of collective identity" (Kearney 1991:59). According to Castles (2000:279), the nation-state is: premised on the idea of cultural as well as political unity....This unity has often been fictitious - a construction of the ruling elite- but it has provided powerful national myths. Immigration and ethnic diversity threaten such ideas of the nation because they create a people without common ethnic origins.... [T] he failure of assimilation policies mean that the new citizens are often not nationals (in the sense of sharing the dominant culture).

\section{WILL ETHNIC CONFLICT PUSH THE WORLD-SYSTEM TO DEMISE?}

Wallerstein argues that four major dilemmas have been worsening for hundreds of years and have now reached the crisis point.

There are three irreversible structural crises that are putting real pressures on global profits-thereby threatening the accumulation of capital that propels the existing system. On top of that, disillusionment with 20 th century movements has caused the elimination of a safety valve that once protected the system. The failures of communism, socialism, and national liberation movements means the removal of the major political mechanism that kept the lid on the pot of world grievances (Dunaway 1999:296-98). 
Because the world-system has surpassed its structural, cultural and ideological "limits to renewal" (Wallerstein 1982:22), we have reached "the end of the world as we know it" (Wallerstein 2003). It is precisely in periods of transition that antisystemic resistance can have the greatest impact. According to Wallerstein:

When a system functions "normally," as the capitalist world-system functioned for several hundred years, people could push and pull, but those actions would only have limited effect.... When a system is in crisis, however, it fluctuates incredibly, and it becomes very unstable. So a little push here and a little push there really has tremendous effect.... It is only in such times of transition that [counter-hegemonic resistance] outweighs the pressures of the existing system to return to equilibria. (Dunaway 1999:298).

The wide array of ethnic conflicts can prove particularly problematic during this transitional crisis of the world-system for two reasons. First, core social movements have severely diminished the capacity of the capitalist class to apply sexism and racism as hegemonic pillars of the world-system. As a result, there is a large "conscience constituency" (Zald and Ash 1966) that supports many oppositional movements of the periphery. Second, even moderate increases in costs to the profit structure of the system can now cause much greater problems than in the past. That is, the multitude of ethnic conflicts may be viewed as a fourth irreversible structural crisis that contributes to the profit squeeze that threatens the world-system as we know it (Wallerstein 2000).

Despite these structural realities, I disagree with Friedman's (1993:234) contention that "ethnification of the nation" is "an aspect of a declining hegemonic order in the global system." I argue, instead, that ethnic differentiation is a fundamental characteristic of the world-system and that there is the highest incidence of ethnic mobilizations during the peak of the hegemon's ascendancy (see Table I and Figure I). What world-system analysts need to explore are the implications of ethnic conflict now that the system has reached its bifurcation point. As ethnic alignments become more central to antisystemic resistance, what are the possible directions in which ethnic conflict will push us, at the system's bifurcation point, towards various possible alternative outcomes (Wallerstein 2000ः309)? How can ethnic movements make capitalism so costly that the world-system will collapse or transform? To answer those questions, I will delineate five areas in which ethnic resistance is "costly" to the world-system:

I. crises of the state;

2. opposition to economic growth agendas and expansion of markets;

3. the legitimation crisis of the capitalist civilizational project;

4. resistance against core ecological domination;

5. the economic and human costs associated with ethnic violence.

\section{ETHNIC MOBILIZATIONS AND CRISES OF THE STATE}

The widespread conventional wisdom seems to be that a dramatic upsurge in ethnic mobilization poses the most fundamental threat to the survival of the nation-state worldwide. ${ }^{6}$ Despite the alarmist sound of such claims, the perceived threat of ethnic resistance to the stability of the state is conceptually flawed and overstated. We must be careful not to assume that all ethnic conflicts are aimed at separatism from or destruction of the state. ${ }^{7}$ Nearly half the contemporary ethnic mobilizations are attempts by groups to secure a higher level of state resources or greater political participation - not to destroy existing national governments. Most of the rest are aimed at relative or limited autonomy, not at sovereignty. Moreover, one-third to one-half of current minority ethnic mobilizations are ideologically, culturally, and ecologically counter-hegemonic, but a majority of those movements are nonviolent and are not seeking to destroy the state. ${ }^{8}$ Why, then, are so many core scholars exaggerating the degree to which

6. This viewpoint is evidenced by the proliferation of books and articles about this topic in the I990s. Mainstream political scientists point to "cultural denationalization" and "cosmopolitanism" as threats to national hegemony. See, for example, Green (2000) who identifies fifteen structural, political, and normative forces that are undermining the capacity of the nation. World-system analysts also make this mistake. For example, Boswell and Stevis (1997:3-4) argue that "the surge of nationalism is driven, in no small part, by the very process of globalization that makes state power less potent. In the face of world integration, dominant ethnic groups demand reinforcement of their national identity and the competitive advantage nationals have within it. Subordinate ethnic populations with identifiable territories (i.e., nations) increasingly seek their own sovereign states as they gain less from having a voice within an increasingly ineffectual and nationalist state.... Deepening integration and neoliberal competition have thus engendered centrifugal processes of declining sovereignty yet rising nationalism."

7. According to Gurr (1994; 1999: Table 3), most nationalist ethnic mobilizations in the I990s were aimed at (a) greater political participation by minorities or at (b) seizing control of state power- not at separating to form new nations. Since Ted Gurr's research purpose is to identify threats to national security, I find his assessment of the lack of decline of the nation-state very compelling.

8. My analysis of 275 groups in the Minorities at Risk Project and 312 case studies shows that the middle classes play a central role in ethnic revitalization movements all over the world. In developing countries, "nationalism and ethnic strife is common in situations where highly skilled individuals - especially intellectuals-are prevented from socially and economically ascending to a degree commensurate with their expertise." By elevating cultural myths to the level of widespread acceptance, such elites attempt to "position themselves as the intermediaries between [the state] and the masses" (Barreto 2001:29). 
ethnic conflicts, indigenous autonomy, and transnational migration threaten the nation-state?

The first explanation is that these scholarly claims are a reflection of cultural and ethnic prejudices that are dominant in the core. On the one hand, there is a rising incidence in the core of ethnic scapegoating, hate crimes, and race-based opposition to immigration. All these are indicators of increasing prejudice and discrimination. On the other hand, Western Europe, Canada, and the United States are polarized from the rest of the world in the degree to which their citizens are preoccupied with ethnic and racial differences. In 2002, the Pew Global Attitudes project asked citizens to rank the significance of five threats facing the world: (a) AIDS and infectious diseases, (b) religious and ethnic hatred, (c) proliferation of nuclear weapons, (d) the widening gap between rich and poor nations, and (e) pollution and environmental degradation (see Table 2). While the Japanese prioritized nuclear weapons and ecological change, citizens of the other core nations much more frequently emphasized religious and ethnic hatreds. In sharp contrast to the predominantly-Caucasian core countries, respondents in Eastern Europe, Latin America, Asia, and Africa were much more likely to prioritize AIDS, the rich/poor gap, or environmental pollution. Despite recent regional ethnic conflicts, Russians view AIDS and other infectious diseases as the greatest danger (Pew Research Trust 2002). Even in most areas where there have been recent ethnic conflicts, a majority of citizens prioritized threats other than religious and ethnic hatred. ${ }^{9}$ The second explanation for the scholarly exaggeration is that much of that academic rhetoric represents political legitimation for increased state repression of minorities. Research about ethnic resistance movements is now heavily funded by core government agencies, foundations, and think tanks that prioritize "national security," not humanitarian benefits for minorities. ${ }^{10}$ Thus, uncritical acceptance of such claims means

9. The only non-core countries in which citizens ranked religious and ethnic hatred as the greatest danger are the $\mathrm{Czech}$ Republic, Jordan, Lebanon, Indonesia, and Nigeria. Clearly, the presence of current ethnic conflict in a region did not cause citizens in most affected countries to prioritize religious and ethnic hatred.

10. The purpose of research like the Minorities at Risk Project and others like it is the construction of "early warning systems" that will permit the core to decide "where to invest scarce monitoring resources," i.e. where to prioritize collection of intelligence information (Gurr 1997:IIO2). Even though the project was initiated using foundation grants with very different goals, the Minorities at Risk Project (2002) at the University of Maryland is now heavily funded by the CIA. We can expect to see future funding of such research integrated into the "US War on Terrorism." For example, the US government
Table 2 - What Do Citizens Rank As the Greatest Danger Facing the World?

\begin{tabular}{lll}
\hline Region & Danger \# 1 & Danger \# 2 \\
\hline Africa & Aids \& Other Infectious Diseases & Rich/Poor Gap \\
Asia & Environmental Change & Rich/Poor Gap \\
$\begin{array}{l}\text { Core: Western Europe, } \\
\text { US, Canada }\end{array}$ & Religious \& Ethnic Hatred & Nuclear Proliferation \\
Core: Japan & Environmental Change & Nuclear Proliferation \\
Eastern Europe & Nuclear Proliferation & Rich/Poor Gap \\
Latin America & Aids \& Other Infectious Diseases & Nuclear Proliferation \\
\hline
\end{tabular}

Source: Analysis of Responses to the Pew Global Attitudes Project (Pew Research Trust 2002: 47-54)

that world-system analysts are ideologically embracing the historical tendency of the core to demonize counter-hegemonic ethnic movements (Dunaway 1999: $288-90){ }^{11}$

Third, many of the claims about the impending decline of the state are just conceptually sloppy. The most obvious mistake is the recent tendency to draw worldwide generalizations from case studies about European ethnonationalism which followed collapse of the USSR. Furthermore, writers fail to recognize that much contemporary conflict is not new, but is, rather, a continuation of conflicts that been begun in previous periods. In many instances what is occurring is not new conflict but a change in strategies and tactics by groups that have been engaging in resistance that spans more than one decade.

Such exaggerated scholarly claims are grounded in another fundamental conceptual flaw. It is doubtful that there has even been a strong "nation-state" in any part of the world-system other than the core, near-core, and a few richer semiperipheries. Indeed, Amin (1990:133) contends that "movements making

began soliciting grant proposals in January, 2002 for university-based research that will support "homeland security" efforts.

11. Core preoccupation with the security threat represented by problems of weakening domestic hegemony is evident in the extent to which this topic appears in publications in political science and international relations. More than roo books about this topic have been published in the last five years, and the number of published articles now reaches into the hundreds, just in academic journals. 
'ethnic' demands" are largely the product of "the failure to build a national state in the periphery." The notion of a world of "nation-states" is an impossible dream of core elites, a segment of that larger modernization myth which seeks to re-create the world in its own image. ${ }^{12}$ Since a majority of peripheral and seimperipheral governments have never achieved "nationhood," the claim that the nation-state is in world-wide decline (Boswell and Stevis 1997; Friedman 1999) is tenuous at best. ${ }^{13}$ Indeed, what most of these writers are complaining about are perceived threats to core states, not to a majority of states worldwide.

I would like to propose four different explanations that will move us away from such demonization of "ethnic others" and direct our attention to that majority of the world's states and peoples that are situated in the periphery and the semiperiphery. Probably the best indicator of the crisis of the state worldwide is a trend that runs counter to core scholarly fads. Much of the current ethnic conflict in the periphery and the semiperiphery is generated from the top-down, not caused by minority resistance (Amnesty International 2002). A majority of the recent instances of ethnic cleansing and genocide have been orchestrated by powerful political elites who often have utilized the government's resources against minorities (Human Rights Watch 2002). To engage in such actions, the state is relying on repression, not on the type of long-term consensus-building that is crucial to the formation of a viable nation-state. A hegemonic order is one in which consent/consensus rather than coercion operates most frequently to achieve popular acquiescence to the dominant agenda (Bell 1976; Friedman 1993; Wallerstein 2000). However, repressive peripheral and semiperipheral states are trapped in an imploding hegemony in which "the ruling class has lost its consensus, i.e., is no longer 'leading' but [is] only 'dominant,' exercising coercive force alone" (Gramsci 1971:275-76).

12. Anthony Smith (1986) has argued that five factors are necessary for the formation of a nation: the construction of a collective name, a common myth of descent, a shared history and culture, a bounded territory, and sense of solidarity. Nagengast (1994: IO9) contends that the ideal state "is one in which the illusion of a single nation-state is created and maintained and in which resistance is managed so that profound social upheaval, separatist activity, revolution, and coups d'état are unthinkable for most people most of the time." Most peripheral and semiperipheral countries attained independence from colonialism in the $20^{\text {th }}$ century, and most of these states have been struggling unsuccessfully throughout the postcolonial period to achieve the core ideal for a nation-state.

13. Wallerstein (2000: 3II) argues that "stateness' of the 'sovereign states' has been increasingly clearly defined and their powers specified and enhanced. Hence we have been moving in the direction of ever 'stronger' state structures that are constrained by an ever 'stronger' interstate system."
Second, peripheral and semiperipheral states are caught in contradictory mandates that are emerging from core universal agendas. There is a structural contradiction between the world-system need for relatively strong states and the universal demand for democraticization. Inherently, the developing state is trapped in a paradox. Tendencies toward homogenizing nationalism and centralized control over territories - the prerequisites to be a real "nation-state" in the world-system - are not democratic, and they may trigger extended resistance from ethnic minorities (Hechter 2000). Consequently, the state is ensnared in a dilemma in which "too much centralization causes rebellion, and too little centralization would cause fragmentation" (Yavuz 200I:2I). In addition, core democraticization agendas create new structures of political opportunity (McAdam, McCarthy and Zald 1996). Because counter-hegemonic resistance cannot emerge in circumstances of extreme state repression (Tilly 1978; Skocpol 1979), ethnic mobilization increases as a state democratizes (Barbosa 1996; Olzak and Tsutsui 1998). Second, ethnic groups will engage in resistance against newly democratic states when minorities have previously been repressed by or fear they will be oppressed by ruling elites (Korovkin 200I; Premdas I99I; Verma 2002).

The thrust for universal democracy is grounded in the "human rights" of people to liberties that cannot be denied or withdrawn by a repressive state. Increasingly, ethnic minorities are"call[ing] the bluff of neoliberalism and its pretenses to democratization" (Graeber 2002:5) by merging that core agenda with demands for redress from "the universality of difference" in which the worldsystem is grounded. Obviously, there is an inherent structural dilemma here. If ethnic minorities and indigenous peoples lay full claim to the "promises" of democracy, they are likely to demand greater and greater autonomy from repressive states and from the interstate system. Core pressures toward democracy can mean "the end of wholly state-led cohesion and the search for new trajectories which...take the self-determined and negotiated positions of the constituent units as paramount"(Osaghae 2001:16-17). As Wilmer (1993:118) points out, core-sponsored international law defines an impossibly contradictory agenda for states. On the one hand, developing governments should follow the core model in which "conquest and discovery a[re] legitimate means of extinguishing aboriginal sovereignty." On the other hand, those same governments are expected to "recogniz $[\mathrm{e}]$ the right of peoples to self-determination."

There is growing evidence that "the diffusion of a world system culture of human rights" (Olzak and Tsutsui 1998:714) will lead to increased ethnic resistance (Brysk 1996; Anaya 1996). Universal human rights and multiculturalism reinforce the tendencies toward ethnic identity formation. While strengthening world capitalist agendas, the recent core ideological focus on multiculturalism has empowered ethnic minorities in the periphery and semiperiphery to resist 
policies of their own governments (Friedman $1997: 83-85$ ). To exacerbate those trends, there has been "a qualitative shift in political structures" that results from "the geometric rise in the number of international organizations... that form alliances with subnational ethnic groups" (Boswell and Stevis 1997:3-4). Two human rights resistance strategies threaten state sovereignty: (a) subnational political realignment with ethnic minorities and (b) supranational alliances with international organizations and movements. ${ }^{14}$ Many ethnic movements play on the sympathies of distant international audiences they hope will move to weaken the position of their states (Pfaff-Czarnecka et. al. 1999).

The "internationalization of indigenous rights" (Brysk 1996; Anaya 1996) is one such universal agenda that threatens state autonomy. Proposals to universalize the concept of indigenous peoples concretize the existence and legal claims of these groups to ecological resources and to political autonomy. United Nations documents illustrate the core-generated conflict between indigenous groups and states. After their governments denied the existence of indigenous peoples, a coalition of Asian groups requested that the United Nations recognize and legitimate these peoples "who are denied the right to govern themselves" (Kingsbury 1998:417). This indigenous claim of the right to political autonomy:

challenges dominant conceptions of the state as the political embodiment of a nation comprising all of the people within that state, and emulates the representation of historical 'nations' connected to particular territory.... "Indigenous peoples" challenge totalizing views of "nation" and the "nation-state" that have frequently made it difficult for identities other than the "nation" to secure recognition and acceptance. "Indigenous peoples" would legitimize such cultural and political units in the way nation-states have been legitimized by "nations" (Kingsbury 1998:422).

Because universal democraticization and human rights agendas stimulate minority demands for equitable treatment, pro-systemic movements can have antisystemic effects, the fourth dilemma of the state. Since at least half the contemporary ethnic mobilizations are aimed at greater political enfranchisement or larger shares of state resources, there is a "revolution of rising entitlements" (Bell I976: 226-27) in which "the pressure to increase services is not necessarily matched by the mechanisms to pay for them." As a result, the costs of state entitlements are steadily increasing all over the world, creating a simultaneous crisis for states and

14. For authors who contend that the loyalty of citizens toward territorial states is weakening, see Rosenau (1997), Ferguson and Mansbach (1996), Strange (1996), Calhoun (1994), Sandel (1996), Hobsbawm (1990), and Robertson. For an empirical study, see Dombrowski and Rice (2000). for the future of the world-system. According to Wallerstein, capitalists are feeling a profit squeeze from the clamor for expanded entitlements.

Ordinary people have three basic claims: they want more education, they want more health services, and they want more guaranteed life income. If you look at legislation over the last two hundred years, the demand level for these human needs has been going up slowly all over the world.... Obviously, the costs are retrieved through a taxation system of one variety or another, and these costs act as a drain on the worldwide accumulation of capital.... What we call neoliberalism is an attempt to reverse these trends, but it has not been spectacularly successful. The reversal of social expenditures is very hard to achieve because such changes trigger a storm of popular resistance (Dunaway 1999:295-96).

Finally, many ethnic mobilizations can contribute to the loss of national hegemony by shifting their resistance away from acquisition of state power, the predominant strategy that characterized $20^{\text {th }}$ century movements (Dunaway 1999:300-30I). Graeber (2002:6-9) contends that the new anarchistic strategies employed by ethnic minorities are "less about seizing state power than about exposing, delegitimizing and dismantling mechanisms of rule while winning ever-larger spaces of autonomy from it." Many contemporary ethnic movements mobilize simultaneously at local, state and international levels, and those resistance strategies will make it impossible for states to operate as the "adjustment mechanisms of the world-system." In the previous century, nationalist movements "served as the moral guarantor of the state structures," and capitalists "relied ever increasingly on the movements to perform on their behalf the function of legitimating the state structure" (Wallerstein 1997:9). Ethnic mobilizations no longer offer this "safety-valve" role to their states.

\section{ETHNIC RESISTANCE AGAINST ECONOMIC GROWTH AGENDAS}

As peripheral and semiperipheral states have integrated their development agendas more deeply into the world-economy, ethnic minorities have often remobilized. Ethnic resistance movements in the periphery and semiperiphery can contribute to the core profit squeeze by limiting core expansion of markets and by slowing the flow of cheap imports. There is a growing body of empirical evidence that recent neoliberal policies have spurred increasing transnational mobilization of indigenous groups and a wide variety of collective actions by poor and middle class ethnic minorities. ${ }^{15}$ Probably half or more of recent ethnic

15. Regarding contemporary ethnogenesis and indigenism as resistance against international economic trends and structural adjustment programs, see StroebeleGregor (1994) and Quijano (1989). 
mobilizations have emerged as resistance against capitalist economic agendas. ${ }^{16}$ Targeting other cultures as markets for core imports simultaneously can have two effects. On the one hand, it increases the likelihood that the capitalist civilizational project will become dominant. On the other hand, new consumption patterns can fuel ethnic resistance (Friedman 1990:314).

Even when the group's resistance is aimed at opposition with the core economic agenda, the national government quite often bears the brunt of local opposition - thereby exacerbating the political crisis of the state. Increased levels of discrimination or linguistic homogenization have been utilized by several states to broaden their export production agendas; as a consequence, minorities have reacted with greater violence and/or ethnonationalist movements. ${ }^{17}$ In this conflation of national and world factors, the state may face a regime crisis grounded in "the capacity of antisystem forces...to successfully challenge the ideological hegemony" (Baruah 1994). When indigenous communities advocate collective control over natural resources, production, marketing, and profit distribution, their resistance is often defined as threats to the "national interest" or to the "national security" in peripheral countries that are expanding export production. As Nash (1995:35) observes about the Zapatista movement, such counter-hegemonic resistance demonstrates "the threat that subsistence systems might pose to global trade agreements." In turn, government repression of such resistance attracts world media attention and contributes to "the development of a global moral community" against such public actions. In such circumstances, the state will be simultaneously pressured by contradictory ideologies and policies from the core.

\section{THE LEGITIMATION CRISIS OF THE CAPITALIST}

\section{CIVILIZATIONAL PROJECT}

The capitalist civilizational project has never been hegemonic enough to silence the dissatisfied voices of subaltern peoples, for the system has achieved, at best, only a tendency toward limited quiescence (Gaventa 1980). Paradoxically, hegemony is weakened because the world-system has structured states in which "the cultures of both the dominant and the oppressed are persistent, leading to myriad

16. I analyzed 275 groups in the Minorities at Risk Project and 312 case studies of ethnic conflict in the r980s and I990s.

17. For case studies, see Morris (200I), Meadwell (1993), Adamson (1980), Mees (200I), Mitra (200I), and Ayres and Saideman (2000). forms of resistance by oppressed groups" (Fenelon 1998:335). Thus, the "capacity of dominant groups to define, constrain, and marginalise the other"'(Greenstein 1994:652-53) is being eroded by ethnic mobilizations. Increasingly, the capitalist civilization project is facing a legitimation crisis not unlike that which Habermas (1973) describes for the capitalist state. That crisis derives from the opening in the world-system of new cultural opportunity structures, a notion I have coined to parallel political opportunity structures (McAdam, McCarthy and Zald 1996).

Opportunity structures are either (a) systemic openings that permit dissent or (b) systemic closings which prevent or discourage opposition. At the level of the world-system, changes in the cultural opportunity structures are conjunctural. In specific situations, these openings or closings may be intentional adjustments, emerging contradictions, or breakdowns in the hegemonic civilizational project fostered by core elites and intelligentsia. Changes in the opportunity structures do not appear from nowhere or at the whim of economic and cultural elites. They are rough adaptations to changes in the political economy of the worldsystem, and they are dialectically related to struggles within the system. When openings occur in the cultural opportunity structure, for whatever reason, mobilization follows, increasing the economic costs associated with repression and/or concessions. In turn, those added costs exacerbate the profit squeeze crises of the system.

There are signs that the cultural opportunity structure of the world-system is opening new windows for ethnic oppositional movements while closing opportunities for the kinds of movements that dominated the $20^{\text {th }}$ century. Wallerstein refers to one such opening that may become a systemic rupture. His observation that universalism is under heavy attack is just as significant as Nietzsche's announcement of the death of God.

The crisis is cultural. The crisis of the anti-systemic movements, the questioning of the basic strategy, is leading to a questioning of the basic premisses of universalist ideology. This is going on in two arenas: the movements where the search for 'civilizational' alternatives is for the first time being taken seriously; and intellectual life, where the whole intellectual apparatus which came into being from the fourteenth century on is being slowly placed in doubt (Wallerstein I99Ib:9I-2).

What, then, are the implications for ethnic and indigenous movements? First, the traditional opening toward the left is undergoing closure, in part because Marxism and the intellectual left accepted the "master narrative" of universal progress. This closure provides new openings for alternative movements. Second, cultural crisis implies an apertura toward the "Other," a breach that widens the prospects for those ethnic movements to popularize ideas about civilizational alternatives. ${ }^{18}$ 
In addition to the openings caused by the questioning of universalism, other cultural opportunities are being created by multiculturalism. In contrast to Friedman (1997), I contend that multiculturalism is not an indicator of decline or disintegration. Rather the rising acceptance of multiculturalism is a hegemonic adjustment that is designed to broaden the appeal of the capitalist civilizational project and to quiet resistance from marginalized ethnic groups. As Amin (1990: 134) observes, "The unity of the modern world-system requires that the core dimension of culture... be universalist. Diversity must serve the universalism that is to be built." For that reason, multiculturalism is a response intended to ameliorate systemic problems as cheaply as possible - as are other such systemic adjustments. Dialectically, however, minorities can use multicultural ideals to push their own agendas into the cultural domain. The rising legitimacy of multiculturalism provides a hegemonic basis of support for the universalism of human rights. In addition, the opening toward multiculturalism in the core helps provide a potential "conscience constituency" for ethnic movements in the periphery.

Transnational migration is a third new cultural opportunity structure. At present, 200 million people live in countries to which they have migrated (Green 2000:82), representing about 3 percent of world population. Although most migrate to developing countries, one-quarter of them move into richer countries, nearly io percent going to the United States. Thus, the core is becoming increasingly ethnically diverse, and many mainstream scholars herald that change as a significant ideological and cultural threat to hegemony (Huntington 1996). Since immigration fuels greater population increases than does the birth rate of U.S. citizens, demographers predict that, by 2050, the U.S. will for the first time in its history no longer have a white numerical majority. These ethnic shifts will ultimately create new political and cultural opportunities for movements that pose alternatives to the capitalist civilizational project.

\section{COUNTER-HEGEMONIC RESISTANCE AGAINST CORE ECOLOGICAL DOMINATION}

Resistance against core ecological hegemony is the fourth area in which ethnic mobilizations are increasingly costly to states and to core expansion. The world-system is attracted to arenas out of its "craving for supplies of scarce

18. By focusing on openings, I do not mean to deny that there are near-permanent cultural closures or zero-opportunity structures. Among other components of the western hegemonic project, racism, law and order, and patriotism stifle ethnic and indigenous mobilization, limit support from potential allies, and justify repressive actions. commodities and for new sources of wealth" (Phillips 1987:78I). When the world-system expands into new zones, "capitalism takes over land and effectively subjects it to its own rules, completely reshaping its organization" (Braudel I98I: vol. 2, 25I). Natural resources and land are exploited to produce exports for the world-economy, generating ongoing resistance from those peoples whose ecosystems have been brought under the reach of the world-system (Dunaway 1996b, 1997).

Wallerstein points to the resultant ecological crisis as one of the three most significant structural contradictions of the world-system.

The profit squeeze is the most insoluble problem of the current system. On the one hand, capitalists are experiencing a profit squeeze from the slow growth of real wages, with the decline of new rural people to pull in as very cheap labor. Then there is the second profit squeeze from the real expenses associated with capitalists being forced to pay for their free ride from the externalization of costs. The world faces the choice of ecological disaster or of forcing the internalization of costs. But forcing the internalization of costs threatens seriously the ability to accumulate capital (Dunaway 1999: 294-95).

In addition to the crisis related to internalization of costs, natural resources are more and more scarce, and there are few ecological zones left to incorporate. There are three ethno-ecological situations in which counter-hegemonic mobilizations occur frequently:

I. minorities whose resources or territories are targeted for appropriation by their national governments or by dominant ethnic groups (Sharma 1995);

2. minorities whose geographical spaces have been subsumed into capitalist economic processes but whose traditional reliance on the environment is in conflict with those modern export activities (Wilmer 1993; Posey 1996);

3. minorities whose ecological spaces are threatened by the terms of multinational trade agreements, such as patenting, genetic modification, and intellectual property rights (Brown 1998; Churchill I99I).

The struggles of indigenous peoples to maintain autonomous control over their ecosystems represent direct threats to states and to core capitalist ecological hegemony. The requirement of a functioning interstate system is that there cannot be any "no-man's-lands, no zones that were not part of some particular state." (Wallerstein I99Ib:190). According to Kingsbury (1998:456), "the concept of 'indigenous peoples carries within it grounds for justification related to prior occupancy," thus linking ethnic identity, land control, and political autonomy in ways that are not characteristic of other ethnic groups. Wilmer (1993:99) puts 
it succinctly: "the reason there is so much mounting international pressure on and attention to indigenous peoples is that they are the only ones with resources left." Indigenes are much more likely than other minorities to be in cultural or religious conflict with the logic of capitalist exploitation of ecosystems (Escobar 1999; Sivaramakrishnan 1995). Control over land, eco-knowledge systems, and traditional economic activities continue to be the key issues in indigenous struggles for autonomy from the state and from the world-system (Smith and Ward 2000). Ethnic minorities mobilize when indigenous ecosystems are redefined as "national assets" to be used to support national participation in the world-economy (Sharma 1995). The state's continuing attempts to expropriate land and ecological resources are likely to trigger stronger indigenous demands for political autonomy. The "public domain" rights of the nation-state are weakened by new international pressures and by new legal regimes that defend indigenous ecosystems and challenge capitalist notions of patent rights (Brown 1998; Churchill I991; Posey 1996; Holley I997; Takeshita 200I).

\section{ECONOMIC AND HUMAN COSTS ASSOCIATED WITH ETHNIC VIOLENCE}

The human costs of ethnic violence are staggering. Since 1945, more than 60 million people have died in ethnic conflicts. In comparison to the Cold War years, the death toll from ethnic conflicts was actually lower in the I99os. Still there are now 7 times more refugees and displaced persons each year than there were in the I970s. Each year since I990, ethnic violence has displaced I3 to I6 million people within their own countries and generated 20 million or more refugees who moved across borders. In many regards, transnational refugees are much more costly to the world-system than are deaths that occur within countries. In addition, the military costs of ethnic repression and peacekeeping, the cost of rebuilding destroyed infrastructure, and the costs of humanitarian relief services are staggering for the individual state and for the international community. A typical inter-ethnic war of the I990s destroyed 42 percent of the schools and health facilities and threw the country into a spiral of economic decline (UNHCR 2002). In areas of extended ethnic violence, the warfare accounts for more than one-third of child deaths, drives half or more of the rural population off their lands, and leaves one-third to one-half of the civilians homeless. In addition, one-quarter to one-half of the women are raped, resulting in escalation of AIDS (Amnesty International 2002; UNHCR 2002).

\section{CONCLUSION}

I disagree with the claim that there is a dramatic increase in ethnic conflict since the end of the Cold War. However, ethnification and indigenism are inher- ent structural contradictions of the modern world-system that will not diminish. Moreover, ethnic mobilizations pose their greatest challenge to the world-system during an age of transition. I emphasize two mechanisms though which ethnic and indigenous resistance helps to drive this transition. Ethnic mobilizations (a) erode the capitalist civilizational project and (b) increase costs to the system in ways that exacerbate the escalating profit squeeze. I identify five ways in which the counter-hegemonic mobilizations of ethnic minorities are costly to the world-system and can push it toward bifurcation and transformation.

When does ethnic conflict become a threat to the survival of the worldsystem? Most obviously, when that accumulated resistance makes it too costly for capitalism to operate in most of the world. Unfortunately, I am not convinced that resistance by ethnic minorities is yet approaching that level. On the contrary, at least half those movements seek to integrate minorities into the failing system. However, these groups represent insurgencies from the very bottom of the system, so they will force capitalists into a lose-lose game over the long run. Repression is costly, but full incorporation would be even more costly. Elimination of the bottom strata weakens the foundational structure of super-exploitation on which the system rests.

What can we expect in the immediate future? Even if we are in a period of declining hegemony and even if ethnic mobilizations will significantly erode and weaken the capitalist civilizational project, there is no immediate good news here for the indigenous peoples and the ethnic minorities of the world. Core degradation and over-consumption of the world ecosystem will continue, further endangering the territories of indigenous peoples. Since disarmament is unlikely, the core and elites in the periphery and semiperiphery will continue to repress in bloody fashion the world's indigenous and ethnic minorities. Eventually, these secular trends and others will reach a threshold or bifurcation point from which a new sort of world-system will emerge after great turbulence.

\section{REFERENCES}

Abdel-Malek, Anouar. (198I). Civilisations and Social Theory. Albany: State University of New York Press.

Adamson, Walter L. (1980). Hegemony and Revolution. Berkeley: University of California Press.

Alonso, Ana Maria. (1994)."The Politics of Space, Time and Substance: State Formation, Nationalism, and Ethnicity." Annual Review of Anthropology 23:379405.

Amin, Samir. (1982). “Crisis, Nationalism, and Socialism.” Pp. 167-232 in Dynamics of Global Crisis, edited by S. Amin, G. Arrighi, A.G. Frank, and I. Wallerstein. New York: Monthly Review Press. 
Amin, Samir. (1990)."The Social Movements in the Periphery: An End to National Liberation?" Pp. 96-138 in Transforming the revolution: Social Movements and the World System, edited by S.Amin, G. Arrighi, A.G. Frank, I. Wallerstein. New York: Monthly review Press.

Amnesty International. (2002). Annual Report. http://www.amnesty.org/

Anaya, S. James. (1996). Indigenous Peoples in International Law. New York: Oxford University Press.

Anderson, Benedict. (1987). Introduction to Southeast Asian Tribal Groups and Ethnic Minorities. Cambridge, MA: Harvard University Press.

Anderson, Benedict. (1991). Imagined Communities: Reflections on the Origin and Spread of Nationalism. London: Verso.

Appadurai, A. (1990). "Disjuncture and Difference in the Global Cultural Economy." In Global Culture: Nationalism, Globalization and Modernity, edited by M. Featherstone. London: Sage.

Ayres, R. William and Stephen Saideman. (2000). "Is Separatism as Contagious as the Common Cold or as Cancer? Testing International and Domestic Explanations." Nationalism and Ethnic Politics 6:9I-II3.

Balibar, Etienne. (199I)."Racism and Nationalism." Pp. 37-68 in Race, Nation and Class: Ambiguous Identities, edited by E. Balibar and I. Wallerstein. London: Verso.

Barbosa, Luiz (1996)."The People of the Forest against International Capitalism Systemic and Anti-systemic Forces in the Battle for the Preservation of the Brazilian Amazon Rainforest." Sociological Perspectives 39:317-33.

Baruah, Sanjib. (1994). "The State and Separatist Militancy in Assam." Asian Survey 34: $863-77$.

Barreto, Amilcar A. (200I)."Constructing Identities: Ethnic Boundaries and Elite Preferences in Puerto Rico." Nationalism and Ethnic Politics 7:2I-40.

Bell, Daniel. (1976). The Cultural Contradictions of Capitalism. New York: Basic Books.

Bhabha, Homi. (1994). The Location of Culture. London: Routledge.

Boswell, Terry and Dimitris Stevis. (1997). "Globalization and International Labor Organizing: A World-System Perspective." Work and Occupations 24:288-308,

Braudel, Fernand. (1981). Civilization and Capitalism, 15th-18th Century. Trans. Sian Reynolds. New York: Harper and Row, 3 vols.

Brown, Michael F. (1998), “Can Culture Be Copyrighted?” Current Anthropology 39: $193-222$.

Brysk, Alison. (1996)."Turning Weakness into Strength: The Internationalization of Indigenous Rights." Latin American Perspectives 23:38-57.

Calhoun, Craig. (1994). Social Theory and the Politics of Identity. London: Blackwell.

Castles, Stephen. (2000). "International Migration at the Beginning of the $2 \mathrm{I}^{\text {st }}$ Century: Global Trends and Issues."International Social Science Journal 165:269-8I.

Champagne, Duane. (1983). "Social Structure, Revitalization Movements and State Building: Social Change in Four Native American Societies." American Sociological Review 48:754-63.

Champagne, Duane. (1989). American Indian Societies: Strategies and Conditions of Political and Cultural Survival. Cambridge: Cultural Survival.
Chee-beng, Tan. (1997). "Indigenous People, the State and Ethnogenesis: A Study of the Communal Associations of the Dayak Communities in Sarawak, Malaysia." Journal of Southeastern Asian Studies 28:263-85.

Chimhundu, Herbert. (1992)."Early Missionaries and the Ethnolinguistic Factor during the Invention of Tribalism in Zimbabwe." Journal of African History 33: 87-109.

Churchill, Ward. (1991). Struggle for the Land: Indigenous Resistance to Genocide, Ecocide and Expropriation in Contemporary North America. Monroe, ME: Common Courage Press.

Cox, Oliver. (1959). The Foundations of Capitalism. New York: Philosophical Library.

Dombrowski, Peter and Tom Rice. (2000). "Changing Identities and International relations Theory: A Cautionary Note." Nationalism and Ethnic Politics 6:83-105.

Dunaway, Wilma A. (1994)."The Southern Fur Trade and the Incorporation of Southern Appalachia into the World-Economy, 1690-1763." Review. 17:215-42.

Dunaway, Wilma A. (1996a). The First American Frontier: Transition to Capitalism in Southern Appalachia, 1700-1860. Chapel Hill: University of North Carolina Press.

Dunaway, Wilma A. (1996b). "Incorporation as an Interactive Process: Cherokee Resistance to Expansion of the Capitalist World-System, 1560-1763." Sociological Inquiry 66:455-70.

Dunaway, Wilma A. (1997)."Rethinking Cherokee Acculturationः Women's Resistance to Agrarian Capitalism and Cultural Change, 1800-1838." American Indian Culture and Research Journal 21:155-92.

Dunaway, Wilma A. (1999). "Crisis, Transition, and Resistance Movements: A Conversation with Immanuel Wallerstein." Appalachian Journal 26:284-305.

Dunaway, Wilma A. (200I). "The Double Register of History: Situating the Forgotten Woman and Her Household in Capitalist Commodity Chains." Journal of WorldSystem Research 7:2-3I. http://jwsr.ucr.edu/

Escobar, Arturo. (1999). "Steps to an Antiessentialist Political Ecology* Current Anthropology 40:1-30.

Fanon, Frantz. (1965). Studies in a Dying Colonialism. Trans. by H. Chevalier. New York: Monthly Review Press.

Fenelon, James V. (1998). Culturicide, Resistance, and Survival of the Lakota ("Sioux Nation"). New York: Garland Publishing.

Ferguson, Yale H. and Richard W. Mansbach. (1996). Polities: Authorities, Identities and Change. Columbia: University of South Carolina Press.

Friedman, Jonathan. (1988). "Cultural Logics of the Global System: A Sketch.” Theory, Culture and Society 5:447-60.

Friedman, Jonathan. (1989). "Culture, Identity and World Process." Review I2:51-70.

Friedman, Jonathan. (1990). "Being in the World: Globalization and Localization." Theory, Culture and Society 7:311-28.

Friedman, Jonathan. (1992). "The Past in the Future." American Anthropologist 94: $837-59$.

Friedman, Jonathan. (1993). "Order and Disorder in Global Systems." Social Research 60: $205-234$ 
Friedman, Jonathan. (1997). "Global Crises, the Struggle for Cultural Identity and Intellectual Porkbarreling: Cosmopolitan versus Locals, Ethnics and Nationals in an Era of De-hegemonisation." Pp. 70-89 in Debating Cultural Hybridity, edited by P. Werbner and T. Modood. London: Zed Books.

Friedman, Jonathan. (1999). "Indigenous Struggles and the Discreet Charm of the Bourgeoisie." Australian Journal of Antbropology ro.

Graeber, David . (2002). "The New Anarchists." New Left Review 13:61-73.

Gaventa, John P. (1980). Power and Powerlessness: Quiescence and Rebellion in an Appalachian Valley. Urbana: University of Illinois Press.

Gramsci, Antonio. (197I). Selections from the Prison Notebooks. Edited and translated by Q. Hoare and G.N. Smith. London: Lawrence and Wishart.

Green, David M. (2000)."The End of Identity? The Implications of Postmodernity for Political Identification." Nationalism and Ethnic Politics 6:68-90.

Greenberg, S. (1980). Race and the State in Capitalist Development. New Haven: Greenwood Press.

Greenstein, Ran. (1994)."The Study of South African Society: Towards a New Agenda for Comparative Historical Inquiry." Journal of South African Studies 20:64I-6I.

Gurr, Ted R. (1994)."Peoples against States: Ethnopolitical Conflict and the Changing World System." International Studies Quarterly 38:347-77.

Gurr, Ted R. (1997)."Ethnopolitical Rebellion: A Cross-Sectional Analysis of the r980s with Risk Assessments for the 1990s." American Journal of Political Science 4I: IO79-IIO3.

Gurr, Ted R. (1999)."The Ethnic Basis of Political Action in the r980s and I990s." Working Paper, Minorities at Risk Project, Center for International Development and Conflict Management, University of Maryland. http://www.cidcm.umd.edu/

Gutierrez, Ramon A. (1991). When Jesus Came, the Corn Mothers Went Away. Stanford: Stanford University Press.

Habermas, Jurgen. (1973). Legitimation Crisis. Boston: Beacon.

Hall, Stuart. (1986). "Gramsci's Relevance for the Study of Race and Ethnicity." Journal of Communication Inquiry I0:5-27.

Hall, Thomas D. (1986). "Incorporation in the World-System: Toward A Critique." American Sociological Review 51:390-402.

Hall, Thomas D. (200I)."World-Systems, Frontiers, and Ethnogenesis: Incorporation and Resistance to State Expansion." Proto-Sociology 15:51-85.

Harff, Barbara and Ted R. Gurr. (1997). "Systematic Early Warning of Humanitarian Emergencies.” Working Paper, Minorities at Risk Project.

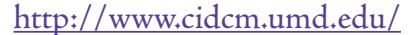

Hechter, Michael. (2000). Containing Nationalism. New York: Oxford University Press.

Henderson, J. Youngblood. (2000). "Postcolonial Ghost Dancing: Diagnosing European Colonialism." Pp. 57-76 in Reclaiming Indigenous Voice and Vision. Vancouver: UBC Press.

Hobsbawm, Eric J. (1990). Nations and Nationalism since 1780. New York: Cambridge University Press.
Holley, Michael. (1997). "Recognizing the Rights of Indigenous peoples to Their Traditional Lands: A Case Study of an Internally-Displaced Community in Guatemala." Berkeley Journal of International Law 15:I19-57.

Hopkins, Terence K. and Immanuel Wallerstein. (1986)."Patterns of Development of the Modern World-System. Review I0:III-46.

Hopkins, Terence K. and Immanuel Wallerstein. (1987)."Capitalism and the Incorporation of New Zones into the World-Economy." Review 10:763-80.

Human Rights Watch. (2002). Annual reports online at http://www.hrw.org

Huntington, Samuel P. (1996). The Clash of Civilizations and the Remaking of World Order. New York: Simon and Schuster.

Kearney, M+ (1991)."Borders and Boundaries of State and Self at the End of Empire." Journal of Historical Sociology 4:520-574.

Kingsbury, Benedict. (1998). "Indigenous Peoples' in International Law: A Constructivist Approach to the Asian Controversy." American Journal of International Law 92:414-57.

Korovkin, Tanya. (200I)."Reinventing the Communal Tradition: Indigenous Peoples, Society and Democratization in Andean Ecuador." Latin American Research Review 36:37-58.

Lamar, H. and L. Thompson, eds. (198I). The Frontier in History: North America and Southern Africa Compared. New Haven: Greenwood Press.

Lawson, Stephanie. (1990). "The Myth of Cultural Homogeneity and Its Implications for Chiefly Power and Politics in Fiji." Comparative Studies in Society and History 32:795-821.

McAdam, Doug, John D. McCarthy \& Mayer N. Zald, eds. (1996). Comparative Perspectives on Social Movements: Political Opportunities, Mobilizing Structures and Cultural Framings. Cambridge University Press.

Maybury-Lewis, David. (1997). Indigenous Peoples, Ethnic Groups and the State. Boston: Allyn and Bacon.

Meadwell, Hudson. (1993). "The Politics of Nationalism in Quebec." World Politics 45: $203-43$.

Mees, Ludger. (200I)."Between Votes and Bullets: Conflicting Ethnic Identities in the Basque Country." Ethnic and Racial Studies 24:798-827.

Merrell, James H. (1989)."'Our Bond of Peace': Patterns of Intercultural Exchange in the Carolina Piedmont, 1650-1750." Pp. 196-222 in Powhatan's Mantle: Indians in the Colonial Southeast, edited by P. H. Wood, G.A. Waselkov, and M.T. Hatley. Lincoln: University of Nebraska Press.

Minorities at Risk Project. (2002). Center for International Development and Conflict Management, University of Maryland. http://www.cidcm.umd.edu/.

Mitra, Subrata K. (200I). "Language and federalism: The Multi-ethnic Challenge." International Social Science Journal 167:5I-60.

Morris, S.D. (200I). "Between Neo-liberalism and Neo-indigenismo: Reconstructing National Identity in Mexico." National Identities 3:239-55. 
Nagel, Joane and Matthew Snipp. (1993)."Ethnic Reorganization: American Indian Social, Economic, Political, and Cultural Strategies for Survival." Ethnic and Racial Studies $16: 203-35$.

Nagengast, Carole. (1994). "Violence, terror and the Crisis of the State." Annual Review of Anthropology 23:109-36.

Nash, June. (1995)."The Reassertion of Indigenous Identity: Mayan Responses to State Intervention in Chiapas." Latin American Research Review 30:7-4I.

Novati, Giampaolo. (1996). "Postcolonial State Versus Ethnicityः A Reassessment of Decolonization in Africa." Latin American Perspectives 23:130-38.

Olzak, Susan and K. Tsutsui. (1998). "Status in the World-System and Ethnic Mobilization." Journal of Conflict Resolution 42:69I-720.

Osaghae, Eghosa E. (200I). "From Accommodation to Self-Determination: Minority Nationalism and the Restructuring of the Nigerian State." Nationalism and Etbnic Politics $7: 1-20$.

Patterson, Orlando. (1982). Slavery and Social Death: A Comparative Study. Cambridge: Harvard University Press..

Pew Research Trust. (2002)."What the World Thinks in 2002: The Global Attitudes Project." http://www.people-press.org/

Pfaff-Czarnecka, Joanne, D. Rajasinghma-Senanyake, Ashis Nandy, and Edmund Gomez. (1999). Ethnic Futures: The State and Identity Politics in Asia. Newbury Park: Sage.

Phillips, Peter D. (1987). "Incorporation of the Caribbean, I650-I700." Review I0: 78I-804.

Posey, Darrell. (1996). "Protecting Indigenous Peoples' Rights to Biodiversity." Environment 38:6-20.

Premdas, Ralph R. (199I). "Fiji under a New Political Order" Asian Survey 31:540-58

Purnell, Jennie. (2002). "Citizens and Sons of the Pueblo: National and Local Identities in the Making of the Mexican nation." Ethnic and Racial Studies 25:213-37.

Quijano, Anibal. (1989). "La nueva heterogenidad structural de America Latina." Pp. 29-52 in Nuevos temas, nuevos contenidos? Las ciencias sociales en America Latina y el Caribe ante el nuevo svglo, edited by Heinz R. Sonntag.. Caracas: UNESCO.

Robertson, Roland. (1995)."Glocalization: Time-Space and HomogeneityHeterogeneity. Pp. 25-44 in Global Modernities, edited by Mike Featherstone, Scott Lash, and Roland Robertson. Thousand Oaks: Sage.

Rodney, Walter. (1973). How Europe Underdeveloped Africa. London: Bogle-L'Ouverture Publications.

Roosens, Eugeen. (1989). Creating Ethnicity: The Process of Ethnogenesis. Newbury Park: Sage.

Rosenau, James N. (1997). Along the Domestic-Foreign Frontier: Exploring Governance in a Turbulent World. Cambridge: Cambridge University Press.

Sandel, Michael. (1996). Democracy's Discontent: America in Search of a Public Philosophy. Cambridge: Cambridge University Press.
Sharma, B.D. (1995). Globalisation: The Tribal Encounter. New Delhi: Har-Anand Publications.

Shulman, Stephen. (1998). “National Integration and Foreign Policy in Multiethnic States." Nationalism and Ethnic Politics 4

Sivaramakrishnan, K. (1995). "Colonialism and Forestry in Indiaः Imagining the Past in Present Politics." Comparative Studies in Society and History 37:3-40.

Skocpol, Theda. (1979). States and Social Revolutions: A Comparative Analysis. New York: Cambridge University Press.

Smith, Anthony. (1986). The Ethnic Origins of Nations. London: Blackwell.

Smith, Claire and Graeme K. Ward, eds. 2000. Indigenous Cultures in an Interconnected World. Vancouver: UBC Press.

Smolicz, Jerzy J. (1998). "Nation-States and Globalization from a Multicultural Perspective: Signposts from Australia." Nationalism and Ethnic Politics 4.

Strange, Susan. (1996). The Retreat of the State: The Diffusion of Power in the World Economy. Cambridge: Cambridge University Press.

Strobele-Gregor, Juliana. (1994)."From Indio to Mestizo to Indio: New Indianist Movements in Bolivia." Latin American Perspectives 21:106-23.

Takeshita, Chikako. (200I)."Bioprospecting and Its Discontents: Indigenous Resistances Legitimate Politics." Alternatives 26:259-83.

Tambini, Damian. (200I). "Post-national Citizenship." Ethnic and Racial Studies 24: 195-217.

Taylor, Peter. (2000). Modernities: A Geobistorical Interpretation. Minneapolis: University of Minnesota Press.

Taylor, William B. and Franklin Pease, Ed. (1994). Violence, Resistance, and Survival in the Americas: Native Americans and the Legacy of Conquest. Washington, DC: Smithsonian Institution Press

Tilly, Charles. (1978). From Mobilization to Revolution. Reading: Addison-Wesley.

UNHCR. (2002). Statistics and trends from the website of United Nations High Commissioner for Refugees. http://www.unhcr.ch.

Varese, Stefano. (1996). “The Ethnopolitics of Indian Resistance in Latin America." Latin American Perspectives 23:58-7I.

Verma, Vidhu. (2002). "Debating Rights in Malaysia: Contradictions and Challenges.” Journal of Contemporary Asia 32:108-3I.

von Werlhof, Claudia. (1997). "Upheaval from the Depth: The Zapatistas, the Indigenous Civilization, the Question of Matriarchy, and the West." International Journal of Comparative Sociology 38:106-3I.

Wade, Peter. (200I)."Racial Identity and Nationalism: A Theoretical View from Latin America." Ethnic and Racial Studies 24:845-65.

Wallerstein, Immanuel. (1974). The Modern World-System I: Capitalist Agriculture and the Origins of the European World-Economy in the Sixteenth Century. New York: Academic Press.

Wallerstein, Immanuel.. (1979). The Capitalist World-Economy. Cambridge: Cambridge University Press. 
Wallerstein, Immanuel. (1982). “Crisis as Transition.” Pp. II-54 in Dynamics of Global Crisis, edited by S. Amin, G. Arrighi, A.G. Frank, and I. Wallerstein. New York: Monthly Review Press.

Wallerstein, Immanuel. (1983). Historical Capitalism. London: Verso Press.

Wallerstein, Immanuel. (1984). The Politics of the World-Economy. Cambridge: Cambridge University Press.

Wallerstein, Immanuel.. (1991a). "The Construction of Peoplehood: Racism,

Nationalism, Ethnicity." Pp. 7I-85 in Race, Nation and Class: Ambiguous Identities, edited by E. Balibar and I. Wallerstein. London: Verso.

Wallerstein, Immanuel. (1991b). Geopolitics and Geoculture: Essays on the Changing World-System. Cambridge: Cambridge University Press.

Wallerstein, Immanuel. (1997). "The ANC and South Africa: The Past and Future of Liberation Movements in the World-System." Fernand Braudel Center, Binghamton University. http://fbc.binghamton.edu/iwsoafri.htm (last verified 3/31/03)

Wallerstein, Immanuel. (2000). The Essential Wallerstein. New York: New Press.

Wallerstein, Immanuel. (2003). "Intellectuals in an Age of Transition." Ch. 2 in New Theoretical Directions for the $21^{\text {st }}$ Century World-System, edited by Wilma A.

Dunaway. Greenwood Press, 2003. http //fbc.binghamton.edu

Wilmer, Franke. (1993). The Indigenous Voice in World Politics since Time Immemorial. Newbury Park, CA: Sage.

Yavuz, M. Haman. (200I)."Five Stages of the Construction of Kurdish Nationalism in Turkey." Nationalism and Ethnic Politics 7:1-24.

Zald, Mayer N. and Ash, Roberta. (1966). "Social Movement Organizations: Growth, Decay, and Change." Social Forces 44:327-4I. 